Full-text Available Online at https://www.ajol.info/index.php/jasem http://ww.bioline.org.br/ja

\title{
Structure of Plants across Habitat Types in Amurum Forest Reserve, Plateau State Nigeria
}

\section{JANFA, N; *FRANCIS, M.J; KAMBAI, C; CHOMINI, M.S; POPOOLA, S.A; UKWADI, M; UKANYIRIOHA, C.J; ERHABOR, T.A; SADIKU, YE; IMOH, JA}

\author{
Department of Forestry Technology, Federal College of Forestry, P.M.B 2019, Jos, Nigeria
}

*Corresponding Author Email: mundi_francis@yahoo.com

Other Author Email: freyjanfa@gmail.com; mundi_francis@yahoo.com; talk2nev@yahoo.com; stevemchoms@gmail.com; adrom835@fcfjos.edu.ng; martinsukwadi@gmail.com; ukanyiriohachidieberej@gmail.com; erhabort@gmail.com

\begin{abstract}
The Amurum Forest Reserve is one of the nature reserves in Plateau State North central Nigeria. Strict Nature reserve is prominent among the methods for in situ conservation of biodiversity in Nigeria and also the world at large. A study was conducted in the Forest across three habitat types in order to measure tree height and diameter at breast height (dbh) of trees. $50 \mathrm{~m} \times 50 \mathrm{~m}$ plots were marked across the habitat types by simple random sampling technique. Trees and shrubs were identified to species level. Measurement were limited to all woody plants with diameter at breast height (dbh) of $\geq$ $10 \mathrm{~cm}$. Data collected was analyzed in excel. A total of 397 woody species were identified during the study period. 87.7 of the plants were shrubs while $12.3 \%$ were trees. The gallery forest had the highest diameter class $(30-35 \mathrm{~cm})$ followed by the savanna $(25-30 \mathrm{~cm})$ and lastly the rocky outcrop with the diameter class of $20-25 \mathrm{~cm}$. The rocky outcrop had the highest number of trees with the lowest dbh $(10-15 \mathrm{~cm})$ while the gallery forest had more trees in the highest diameter class (30-35) (Figure 2). The highest mean height distribution in the Gallery forest shows that the plant communities in this habitat type has grown over the years without disturbance since the place is a protected site. Therefore, other surrounding bushes should be protected in order to preserve species from local extinction.
\end{abstract}

\section{DOI: https://dx.doi.org/10.4314/jasem.v25i5.25}

Copyright: Copyright $(02021$ Janfa et al. This is an open access article distributed under the Creative Commons Attribution License (CCL), which permits unrestricted use, distribution, and reproduction in any medium, provided the original work is properly cited.

Dates: Received: 20 March 2021; Revised: 27 April 2021; Accepted: 07 May 2021

Keywords: Woody plant, Structure, Amurum Forest Reserve Protected area, Amurum Forest Reserve

The accurate measurement of tree height and diameter at breast height (dbh) remains a very important input variable for growth and yield models and are important predictive models for determining canopy and thickness of forests (Liu et al., 2017). These two parameters are the most important factors in surveys, production and management of forest resources and detailed research on forest communities because they can be used to calculate the volume, site index, growth, biomass and carbon stock (Lei et al., 2009; Vargaslarreta et al., 2009; Daniel and Jeffery, 2009). Approximately, one third of the world's land Ecosystem is covered with forest and 50\% of such ecosystem is found in the tropics but are threatened by anthropogenic activities to the extent that the forests are almost reduced to mere grass lands (FAO, 2015; Olajuyigbe and Adaja, 2014; Oke and Odebiyi, 2007; Parthassarathy, 2001; Awotoye and Adebola, 2013). The Amurum Forest Reserve is one of the nature reserves in Plateau State North central Nigeria. Strict Nature reserve is prominent among the methods for in situ conservation of biodiversity in Nigeria and also the world at large (Adenkunle et al., 2013). A woody plant is any plant that has wood as its structural tissue and is either a tree, shrub or a liana which is usually described as a perennial plant whose stems and larger roots are reinforced with wood produced from secondary xylem and contains roots that are usually covered by a layer of bark (Chase and Mark, 2004). The importance of woody species to man cannot be overemphasized. Beyond their economic value, shrubs and trees act as biological filters by helping to cleanse the environment of pollutants such as oxides of carbon, toxic gases and heavy metals (Chakraverty and Jain, 1984).

Seventy percent of the world's plants and animals live in forests and are losing their habitats to deforestation, according to national geographic. Loss of habitat leads to species extinction and also has negative consequences for medicinal research and local populations who rely on the plants in the forest for medicine (Alina, 2005). Hence, the significance of this study, aimed at identifying and documenting species, so as to help conserve such places because of their benefits to the environment. 


\section{MATERIALS AND METHODS}

Study Area: The study was carried out in Amurum Forest Reserve. The forest is about 300ha and is located $15 \mathrm{~km}$ North east of Jos in North-Central Nigeria $\left(09^{0} 53^{\mathrm{N}} \mathrm{N}, 08^{0} 59^{\circ} \mathrm{E}\right)$ and it is $128 \mathrm{~m}$ above sea level (Vickery and Jones, 2003). Amurum Forest is one of the important bird areas (IBA) in Nigeria with at least 278 bird species. The reserve houses some endermic bird species, Rock firefinch (Lagonosticta sanguinodorsals) and Jos Plateau Indigobird (Vidua Maryae) (Ezealor, 2001). Other faunal species include rock hyraxes, Bats, Rabbits and several species of Reptiles (Ibrahim, 2002). It comprises of three major habitats-the gallery forest, Savannana wood land and Rocky outcrop, all of which differs remarkably in floristic composition (Yessoufon et al., 2012). Temperature ranges from $8^{\circ} \mathrm{C}$ to $38^{\circ} \mathrm{C}$, and mean annual rainfall is $1411 \mathrm{~mm}$. Some common tree species include Khaya senegalensis, Daniella oliveri, Parkia biglobasa, Lophura lauceolata, Ficius species (Ezealor, 2001).

Data Collection: $50 \mathrm{~m}$ x $50 \mathrm{~m}$ plots were marked across the habitat types by simple random sampling technique (Daru et al., 2015). A total of 9 plots, 3 each across the three habitat types were measured. Trees and shrubs were identified to species level. Measurement were limited to all woody plants with diameter at breast height $(\mathrm{dbh})$ of $\geq 10 \mathrm{~cm}$. With this minimum diameter at breast height, most of the species of the woody plants were measured. The two parameters assessed in each sample plot were diameter at breast height (dbh) using the veneer caliper and height of all trees in each plot using the Haga altimeter. The GPS was also used to take coordinates of all the trees species in the plots (Figure 1).

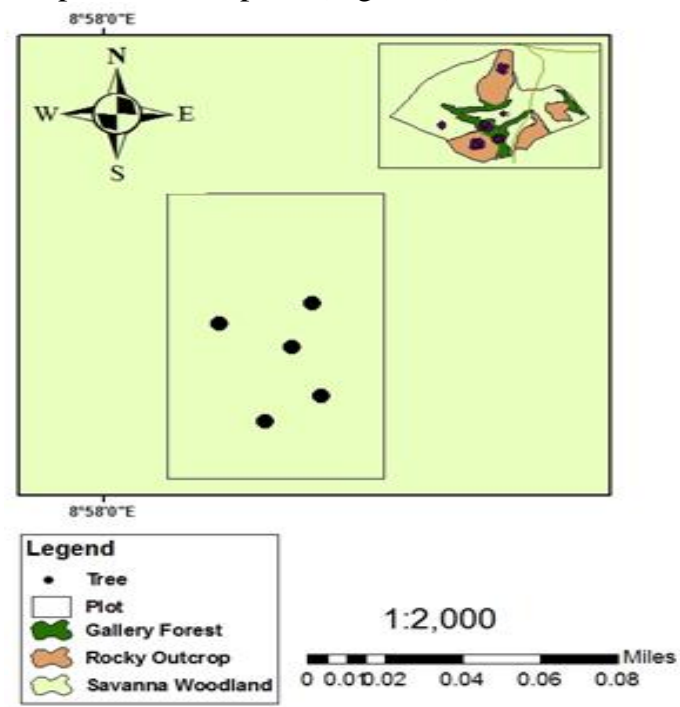

Fig 1: Map Showing the Habitat types and Location of sampling plots

\section{RESULTS AND DISCUSSION}

A total of 397 woody plants belonging to 49 species were identified during the study period (Table 1).

Table 1: List of Woody Species across Family and life Form in Amurum Forest Reserve, Plateau State Nigeria

\begin{tabular}{|c|c|c|}
\hline Species & Family & Life Form \\
\hline Ficus cordata & Moraceae & Shrub \\
\hline Ficus abutilifolia & Moraceae & Shrub \\
\hline Ficus platyphylla & Moraceae & Shrub \\
\hline Rhus natelensis & Anacardiaceae & Shrub \\
\hline Euphorbia desmondii & Euphorbiaceae & Shrub \\
\hline Albizia zygia & Mimosoideae & Tree \\
\hline Holarrhena floribunda & Apocynaceae & Shrub \\
\hline Allophylus nigericus & Sapindaceae & Shrub \\
\hline Jasminum dichotomum & Oleaceae & Shrub \\
\hline Sterculia setigera & Sterculaceae & Tree \\
\hline Ficus glumosa & Moraceae & Shrub \\
\hline Parkia biglobosa & Fabaceae & Tree \\
\hline Erythrina Abyssinica & Leguminosae & Shrub \\
\hline Lantana camara & Verbanaceae & Shrub \\
\hline Kleinia cliffordiiana & Asteraceae & Shrub \\
\hline Stegandaenia araliacea & Apiaceae & Tree \\
\hline Euphorbia kamerunica & Euphorbiaceae & Shrub \\
\hline Dichrostachys cinerea & Mimosaceae & Shrub \\
\hline Pachystela pobeguineana & Sapotaceae & Tree \\
\hline Heeria insigniis & Anacardiaceae & Shrub \\
\hline Croton zambesicus & Euphorbiaceae & Shrub \\
\hline Acacia ataxacantha & Leguminosae & Shrub \\
\hline Heeria pulcherrima & Anacardiaceae & Shrub \\
\hline Bridelia ferruginea & Euphorbiaceae & Shrub \\
\hline Ochna schweinfurthiiana & Ochnaceae & Tree \\
\hline Ziziphus mucronata & Rhamnaceae & Shrub \\
\hline Pterocarpus erinaceus & Leguminosae & Shrub \\
\hline Anogeissus leiocarpus & Combretaceae & Tree \\
\hline Daniellia oliveri & Fabaceae & Tree \\
\hline Uvaria chamae & Annonaceae & Shrub \\
\hline Ekebergia senegalensis & Meliaceae & Shrub \\
\hline Rhus natelensis & Anacardiaceae & Shrub \\
\hline Annona senegalensis & Annonaceae & Shrub \\
\hline Guira senegalensis & Combretaceae & Shrub \\
\hline Perinari curatellifolia & Chrysobalanaceae & Shrub \\
\hline Olax subscorpisidea & Olacaceae & Shrub \\
\hline Syzygium guineense & Myrtaceae & Tree \\
\hline Terminalia avicennioides & Combretaceae & Shrub \\
\hline Strophanthus sarmentosus & Apocynaceae & Shrub \\
\hline Carissa edulis & Apocynaceae & Shrub \\
\hline Diospyros spp & Ebanaceae & Shrub \\
\hline Combretum spp & Combretaceae & Shrub \\
\hline Dichrostachys cinerea & Mimosaceae & Shrub \\
\hline Psorospermum febrifugum & Hypericaceae & Shrub \\
\hline Hymonocardia acida & Phyllanthaceae & Shrub \\
\hline Keeta venosa & Rubiaceae & Shrub \\
\hline Vitex doniana & Verbanaceae & Tree \\
\hline Brideliia ferruginea & Euphorbiaceae & Shrub \\
\hline Ekebergia senegalensis & Meliaceae & Shrub \\
\hline Pericopsis laxiflora & Leguminosae & Shrub \\
\hline Bersema abyssinica & Melianthaceae & Shrub \\
\hline Psychotria psychotrioides & Rubiaceae & Shrub \\
\hline Manilkara multineruis & Sapotaceae & Tree \\
\hline Cleridendrum volubile & Lamiaceae & Shrub \\
\hline Dialium guineense & Leguminosae & Tree \\
\hline Santaloides afzelii & Connaraceae & Shrub \\
\hline Olea capensis & Oleaceae & Shrub \\
\hline Keetia corneliia & Rubiaceae & Shrub \\
\hline Saba senegalensis & Apocynaceae & Shrub \\
\hline Diospyros ferrea & Ebanaceae & Tree \\
\hline Fadogia spp & Rubiaceae & Shrub \\
\hline Opilia celtidifolia & Opiliaceae & Shrub \\
\hline Sericanthe chevalieri & Rubiaceae & Shrub \\
\hline Pavetta spp & Rubiaceae & Tree \\
\hline Cleistopholis glauca & Annonaceae & Tree \\
\hline Ficus citricifolia & Moraceae & Tree \\
\hline Paullinia pirinita & Sapindaceae & Shrub \\
\hline Bersema abyssinica & Melianthaceae & Tree \\
\hline Mitragyna spp & Rubiaceae & Tree \\
\hline Erythrina sigmodia & Leguminosae & Tree \\
\hline Tinnea spp. & Lamiaceae & Tree \\
\hline
\end{tabular}

Tinnea spp.

JANFA, N; FRANCIS, M.J; KAMBAI, C; CHOMINI, M.S; POPOOLA, S.A; UKWADI, M; UKANYIRIOHA, C.J; ERHABOR, T.A; SADIKU, YE; IMOH, JA 
These plants belong to different families. Shrubs were the most dominant species identified in the forest. 348 shrubs were identified which represents $87.7 \%$ and the trees were $12.3 \%$. Family composition of trees and shrubs species in the area is presented in appendix 1.7 of the species belong to the family Rubiaceae followed by moraceae and Euphorbiaceae (with 5 species each). The families with the least species representations were Sapindaceae, Fabaceae,
Verbanacea, Vimosaceae, Sapotaceae, Leguminosae, Melaceae, Melianthaceae and Ebanaceae with two species each. The gallery forest had the highest diameter class $(30-35 \mathrm{~cm})$ followed by the savanna $(25-$ $30 \mathrm{~cm}$ ) and lastly the rocky outcrop with the diameter class of $20-25 \mathrm{~cm}$. The rocky outcrop had the highest number of trees with the lowest dbh $(10-15 \mathrm{~cm})$ while the gallery forest had more trees in the highest diameter class (30-35) (Figure 2).

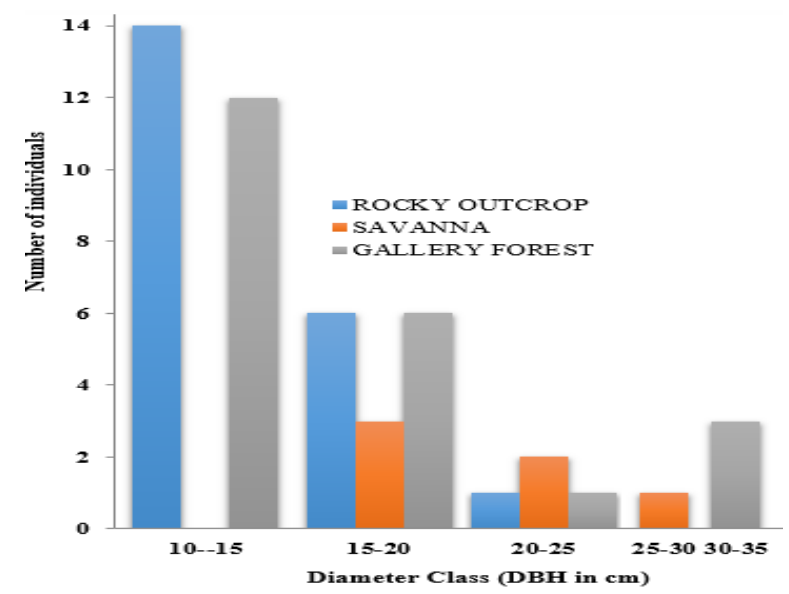

Fig 2: Diameter distribution of trees $(\geq 10 \mathrm{~cm})$ in the three habitat types at Amurum Forest Reserve

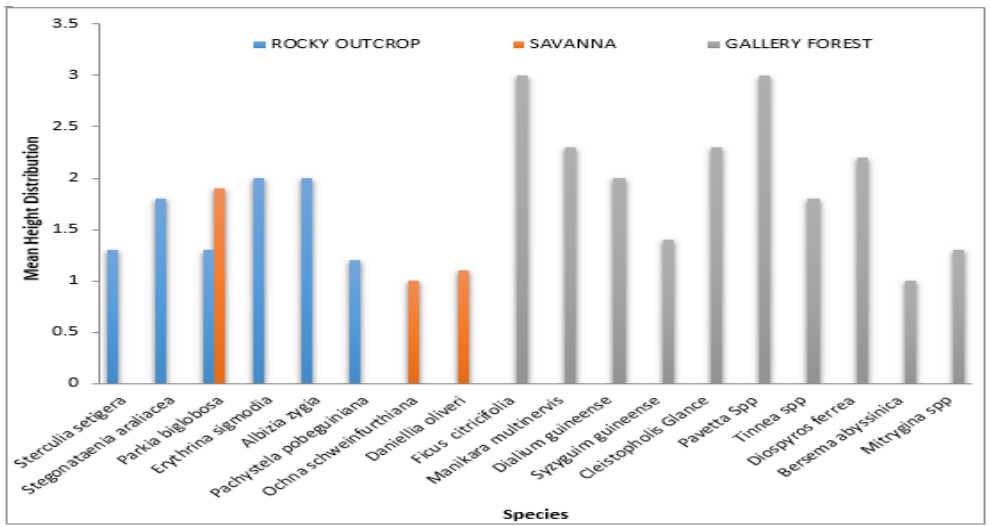

Fig 3: Mean Height (m) Distribution of Trees at Amurum Forest Reserve

The gallery forest had the highest mean height distribution followed by the rocky outcrop and then the savanna with the least mean height distribution (figure 3). The highest mean height distribution in the Gallery forest shows that the plant communities in this habitat type has grown over the years without disturbance since the place is a protected site. Plants are expected to grow with age and increase in height and diameter when there is minimal or no disturbance at all (Adenkunle et al., 2013). The description of forest structure is commonly based on the aggregation of individual plant measures (e.g. density, tree diameter at breast height distribution. Pereira et al., (2001) recorded highest canopy cover in an undisturbed area while light intensity on the forest floor was high in the disturbed forest. Sang (2009) followed the same trend. The decrease in canopy cover and increased light intensity in the Rocky outcrop and savanna woodland was probably responsible for the low mean height distribution in these two habitats. Todaria et al., (2010) also recorded higher density of shrubs and herbs in undisturbed stand while maximum herb and shrubs species richness was recorded in the moderately disturbed forest. In-situ preservation through the establishment of a natural reserve as a biodiversity conservation apparatus has shown to be one of the most effective and least expensive means to protect biodiversity. Protected areas, such as Amurum 
Forest Reserve, often provide habitat and protection for threatened and endangered species in addition to maintaining ecological processes (Dudley, 2008). Amurum forest reserve is a vulnerable site of conservation concern because of its small size and proximity to the urban community of Jos. Though the reserve is a protected area, there are still a few sporadic cases of wood cutting and setting of fire (Abiem, 2013). This has been recorded in the woodland savanna and some parts of the rocky outcrop. The presence of water in the Riparian forest is probably one of the reasons for the robust nature of the plants in the habitat. This is similar with the findings of Molles, (2008) who stated that Riparian zones are transition zones between an upland terrestrial environment and an aquatic environment and therefore support biodiversity. In summary, the gallery forest had Cleistopholis glauca with the highest diameter distribution between $30-35 \mathrm{~cm}$ while Manilkara multnervis, Syzygium guineense, Dialium guineense, Tinnea spp, Pavetta spp, Diospyros ferrrea and Bersema abyssinica with the lowest diameter distribution between $10-15 \mathrm{~cm}$. The highest diameter range of species in savannah was $25-30 \mathrm{~cm}$ with only Parkia biglobosa and no species in the diameter class of $10-15 \mathrm{~cm}$. The rocky outcrop had the highest diameter range of species in $20-25 \mathrm{~cm}$ with only Sterculia setigera while Stegonataenia araliaceae, Parkia biglobosa, Erythrina sigmodia, Abizia zygia, Pachystela pobeguiniana and Sterculia setigera with the lowest diameter distribution between $10-15 \mathrm{~cm}$ (Figure 2)

Conclusion: This research shows the importance of nature Reserves in encouraging the growth of trees and supporting other biodiversity. Therefore, other surrounding bushes should be protected in order to preserve species from local extinction and for the benefit of ecosystem services to the environment.

Acknowledgement: We hereby acknowledge A.P. Leventis Ornithological Research Institute for allowing us in to the Forest Reserve.

\section{REFERENCES}

Abiem, I (2013): Earthworms, Soil Nutrient and plant Diversity of Amurm Forest Reserve and Its Surrounding Area. M Sc. Thesis, 'University of Jos, Nigeria Pp 71.

Adenkunle, VAJ; Olagoke, AO; Akindele, SO (2013). Tree species diversity and structure of a Nigerian strict nature Reserve. Trop. Ecol. 54 (3): 275-289.

Chase, Mark, W (2004). "Monocot relationships: an overview". Amer. J. of Bot. 91 (10): 1645-1655.
Daniel, L; Jeffery, G (2009). A height-diameter curve for longleaf pine plantations in the gulf coastal plain. Southern J. of Appl. Fores. 33 (4), 164-170.

Daru, BH; Yessoufou, K; Nuttman, C; Abalaka, J (2015). A preliminary study of birds use of fig Ficus species in Amurum forest reserve, Nigeria. Malimbus 37: 115 .

Dudley, N (2008). Guidelines for Applying Protected Areas Management Categories. (IUCN: Switzerland).Pp 86.

Ezealor, AU (2001). In: Fishpool, L.D.C., Evans, M. I., Eds. Important Bird Areas in Africa and Associated Island: Priority site for conservation. Pisces publication And Bird Life International (Bird Life conservation series NO.11), Newbury And Cambridge, UK.Pp 2-3.

Ibrahim, MI (2002). Renewable Natural Resources. Draft Action Plans for Laminga Community Forest (Amurum). Nigerian Conservation foundation (NCF) Pp. 2-5.

Lei, XD; Peng, CH; Wang, HY; Zhou, XL (2009). Individual height-diameter models for young black spruce (Picea mariana) and jack pine (Pinus banksiana) plantations in New Brunswick, Canada. Fores. Chron. 85(1): 43-56.

Liu, M; Feng, Z; Zhang, Z; Ma, C; Wang, M; Lian, B; Sun, R; Zhang, L (2017). Development and evaluation of height diameter at breast models for native Chinese Metasequoia. PLOS ONE 12 (8).

Molles, MC Jr (2008). Ecology: Concepts and Applications (4th ed.). New York: McGraw-Hill. Pp 291.

Sang, W (2009). Plant diversity patterns and their relationships with soil and climatic factors along an altitudinal gradient in the middle Tianshan Mountain area, Xinjiang, China. Ecol. Res. 24: 303-314

Vargaslarreta, B; Castedodorado, F; AlvarezGonzalez, Gabriel, J; Barrionta, M; Cruzcobos, F (2009). A generalized height-diameter model with random coeficients for uneven-aged stands in Elsalto, Durango, Mexico. Forestry 84(4): 445-462.

Yessoufou, K; Michelle VanDer, B; Abalaka, J; Daru, BH (2012). Evolution of fig- Frugivore Interactions in West Africa. Isr. J. of Ecol. and Evol. 58:39-51. 